\title{
Hormone Ontogeny in the Ovine Fetus. IV. Serum Somatomedin Activity in the Fetal and Neonatal Lamb and Pregnant Ewe: Correlation with Maternal and Fetal Growth Hormone, Prolactin, and Chorionic Somatomammotropin
}

\author{
PETER D. GLUCKMAN, ${ }^{(24)}$ KNUT UTHNE, DENNIS M. STYNE, SELNA L. KAPLAN, ABRAHAM M. \\ RUDOLPH, AND MELVIN M. GRUMBACH ${ }^{(2 \pi i)}$ \\ Department of Pediatrics and Department of Medicine (K.U.), University of Californio San Francisco, San Francisco, \\ California USA
}

\section{Summary}

Somatomedin (SM) activity was measured by a placental membrane receptor assay using ${ }^{125} 1$-labeled somatomedin $A$, as radiofigand in serum samples obtained from 33 ovine fetuses, 14 neonatal lambs, 8 pregnant, and 3 postpartum ewes. The mean serum concentration of $\mathbf{S M}$ activity in eight adult rams was 2.06 $\pm 0.12 \mathrm{U} / \mathrm{ml}$. In fetal sheep, SM activity was detected at 66 days gestation (term 147 days), in the youngest fetus studied. Before 100 days of gestation, $S M$ was lower $(P<0.001)$ in fetal sheep $(1.08 \pm 0.18 \mathrm{U} / \mathrm{ml})$ than in adult rams. In fetuses between 101 and 125 days, $S M$ rose $(P<0.001)$ to $2.64 \pm 0.32 \mathrm{U} / \mathrm{ml}$. In late gestation fetal serum $S M$ fell but during the neonatal period it rose to $3.38 \pm 0.3 \mathrm{U} / \mathrm{ml}$, higher $(P<0.01)$ than that in adult rams. Serum SM activity in the pregnant ewe prior to 100 days was 1.01 $\pm 0.11 \mathrm{U} / \mathrm{ml}$, increased $(P<0.05)$ to $1.75 \pm 0.21 \mathrm{U} / \mathrm{ml}$ between 125 days and term, and rose further to $2.56 \pm 0.32 \mathrm{U} / \mathrm{ml}$ in the postpartum period. Maternal concentrations of serum SM in late gestation were significantly less than in the fetus. Gel chromatog. raphy of fetal, maternal, and neonatal sera indicated that over $90 \%$ of SM activity circulated in high-molecular weight form. The rise in SM activity in fetal serum between 100 and 125 days parallels the rise in fetal growth hormone and prolactin concentrations; however, in maternal serum the increase in SM activity is associated with rising maternal chorionic somatomammotropin concentrations.

\section{Speculation}

Somatomedin is present in fetal ovine serum and in late gestation may be generated mainly by fetal pituitary hormones. In contrast, somatomedin in the pregnant ewe appears to be regulated by chorionic somatomammotropin.

Mammalian fetal growth has generally been considered to be independent of fetal pituitary growth hormone $(\mathrm{GH})(3,13,4)$. However, several studies have shown an association in humans bewteen birth size and plasma somatomedin (SM) activity as measured in several assay systems $(2,6,18)$. The present study reports the ontogeny of serum concentrations of SM activity as determined in a human placental membrane radioreceptor assay in fetal and neonatal sheep. The relationship of these concentrations to possible hormonal regulators of SM generation in the fetus and pregnant ewe is discussed.

\section{METHODS}

Samples: Samples were obtained from 33 ovine fetuses between 66 days gestation and term ( 147 days) by cardiac puncture during hysterotomy as previously described (9). Additional serum samples were obtained from 14 lambs and 8 pregnant and 3 postpartum ewes via an indwelling femoral venous catheter, and by jugular puncture from 8 rams at least 2 years of age. The serum was stored at $-20^{\circ}$ until assay.

Assay Procedure: SM was concentrated from Cohn fraction IV1 of human plasma (Cutter Laboratories, Berkeley, CA) utilizing acid-ethanol extraction, formic acid extraction and Sephadex gel chromatography (21). Fractions with a Kd value of 0.3 to 0.5 on Sephadex G-50 chromatography eluted with $0.5 \mathrm{M}$ acetic acid were pooled and purified further by ion exchange chromatography using carboxymethylcellulose (CM-52 Whatman). The sample was applied in $0.1 \mathrm{M} \mathrm{NH}$ Ac, $\mathrm{pH} 4.0$ and eluted over a $\mathrm{pH}$ gradient from 4.7 to 6.9 . SM activity was determined in eluate by the active fraction that eluted in the most acidic position $(\mathrm{pH} 5.0$ to 5.2) was defined as SM-Al and was purified further by exclusion chromatography on Sephadex G-50. This preparation had a receptor assay activity of $1350 \mathrm{U} / \mathrm{mg}$ (I unit of SM activity being defined as the activity in a $I \mathrm{ml}$ aliquot of pooled serum obtained from 80 adults) and was used as the radioligand in the human placental membrane receptor assay for somatomedin activity. The SM-A1 was iodinated by a modification of the lactoperoxidase method (20). The free iodine was separated from labeled peptides by rechromatography on CM-cellulose as described above.

Particulate membrane fractions from human placentae were prepared and the radioreceptor assay for SM activity performed by the procedure of Marshall et al (15). A pool of serum from 80 adults was used as a reference standard and was defined as having $\mathrm{l}$ unit SM activity per $\mathrm{ml}$. Unextracted human and ovine sera displaced $\mathrm{I}^{125}-\mathrm{SM}-\mathrm{Al}$ in a parallel fashion. Because heparinized plasma did not demonstrate consistent parallelism in the assay only serum samples were assayed. The activity measured by the assay demonstrated growth hormone dependence as evidenced by measurements in acromegaly $(3.5 \pm 0.4 \mathrm{U} / \mathrm{ml})$, normal adults $(1.06 \pm 0.04 \mathrm{U} / \mathrm{ml})$, and hypopituitary dwarfism $(0.37 \pm 0.3 \mathrm{U} /$ $\mathrm{ml}$ ); the interassay variation was $6 \%$ and the minimal detectable dose 0.01 units (16). Each sample was assayed in quadruplicate at a minimum of 2 dilutions and any values not fulfilling criteria of parallelism and linearity were rejected.

Gel Filtration Siudies: To assess the relative amount of SM circulating in association with its binding protein, $2 \mathrm{ml}$ serum 
from selected fetuses, mothers and neonates was applied to Sephadex $\mathrm{G} .50(1.5 \times 60 \mathrm{~cm})$ in $0.05 \mathrm{M}$ Tris, pH 7.6, and a marker of free ${ }^{125} \mathrm{I}$ was added. Fractions collected between the void volume and the complete elution of albumin, as judged by the OD at 280 $\mathrm{nm}$, were pooled and an aliquot measured as an estimale of bound SM activity. The eluates which followed until the elution of the $I^{125}$ marker were pooled separately and an aliquot portion measured for estimation of "free" SM activity.

Statistics: Regression curves were calculated by computer by the method of least squares. Comparison between groups was by analysis of variance for unequal sized groups. Results are expressed as mean $\pm S E$.

\section{RESULTS}

SM activity was detected in all fetal, maternal, and neonatal sera. The SM activity in 8 aduit rams was $2.06 \pm 0.12 \mathrm{U} / \mathrm{ml}$. The SM activity in fetal and neonatal sheep is shown in Figures 1 and 2. Prior to 100 days gestation the $S M$ concentration is $1.08 \pm 0.18$ $\mathrm{U} / \mathrm{ml}$, lower ( $\mathrm{p}<0.001$ ) than the $\mathrm{SM}$ in adult rams. Between 100 and 125 days, fetal SM activity rose to $2.64 \pm 0.32 \mathrm{U} / \mathrm{ml}$, higher $(p<0.001$ ) than that in the younger fetuses. Between 126 and 150 days gestation, SM activity fell $(\mathrm{p}<0.01)$ to $2.09 \pm 0.11 \mathrm{U} / \mathrm{ml}$. In the neonate ( $1-30$ days postpartum), SM activity was significantly higher $(3.93 \pm 0.3 \mathrm{U} / \mathrm{ml})$ than in the fetus or adult. In two infant lambs, 60 days postpartum SM activity was comparable to that in the adult $\operatorname{ram}(1.65,2.20 \mathrm{U} / \mathrm{ml})$.

$\mathrm{SM}$ activity in the ewe is shown in Figure 2. In pregnant ewes of less than 100 days gestation, $S M$ activity was $1.01 \pm 0.11 \mathrm{U} / \mathrm{ml}$, lower than in the adult ram $(p<0.001)$. In pregnant ewes of 101 days to term, SM activity was higher $(p<0.05)$ at $1.75 \pm 0.2 \mathrm{I} \mathrm{U/}$ $\mathrm{ml}$ and rose further in the postpartum period (0-7 days) to 2.56 $\pm 0.32 \mathrm{U} / \mathrm{ml}$ (Fig. 2). SM activity in the pregnant ewe between

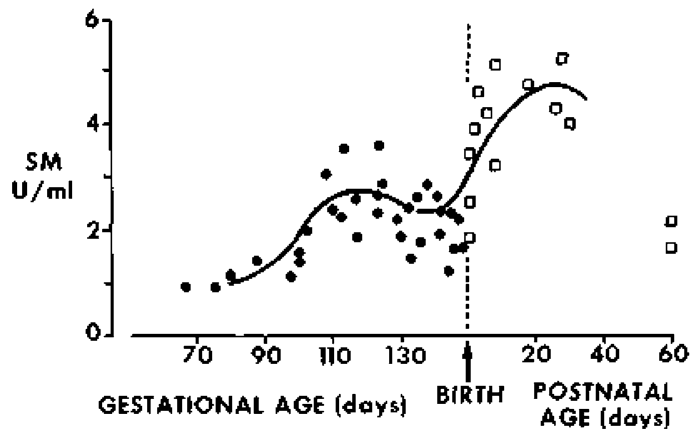

Fig. I. Somatomedin activity in the ovine fetus $(O)$ and lamb (D) is plotted against postconceptual age in days. The regression curve was calculated by the method of least squares.

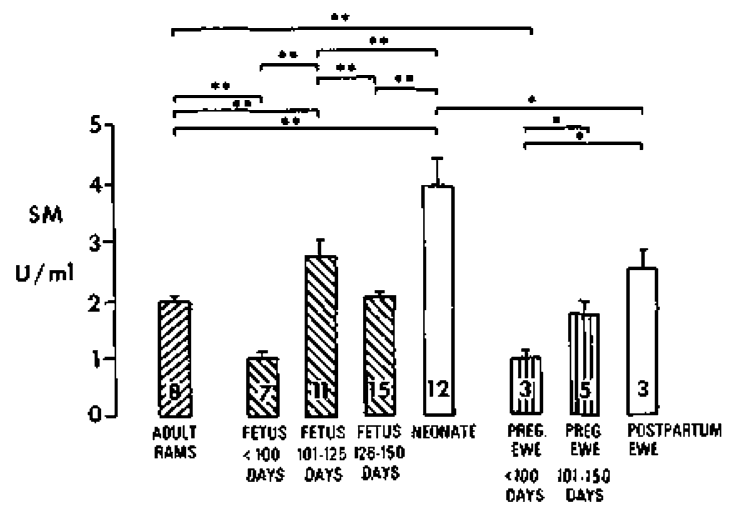

Fig. 2. Comparison of somatomedin activity in the adult ram, fetal and neonatal lamb, the pregnant and postpartum ewe. Statistical differences calculated by analysis of variance for unequal sized groups are shown by the horizontal lines. ${ }^{*} P<0.05,{ }^{* *} P<0.01$.

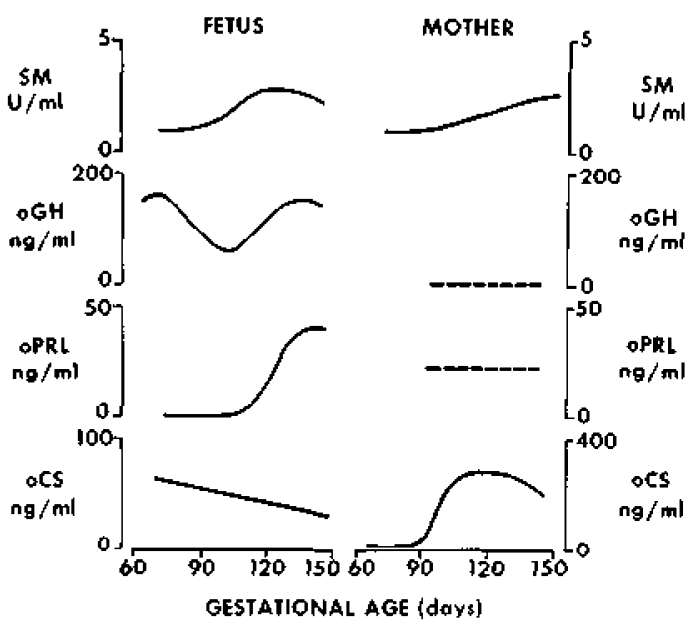

Fig. 3. Comparison of the change in serum SM activity in the fetus and pregnant ewe with the pattern of circulating fetal and maternal oCS, $O G H$ and $O P R L$ from 60 days gestation to term. The curves represent statistically significant regression curves calculated by the method of least squares. There was no significant relationship between the concentration of maternal serum oPRL or $O G H$ and gestational age. The $O G H$, oPRL and oCS data are according to Gluckman et al. $(7,8,9)$.

101 and 150 days was less $(p<0.05)$ than in the fetus $(2.32 \pm 0.11$ $\mathrm{U} / \mathrm{ml}$ ) over a comparable gestational period. Similarly, SM activity in the postpartum ewe was less $(p<0.05$ ) than in the neonatal lamb.

Exclusion chromatography on Sephadex gel at neutral $\mathrm{pH}$ of samples of fetal (133 days), maternal (116 days) and neonatal (5 days) sera demonstrated no detectable $(<10 \%)$ SM activity in the low molecular weight range; all activity was recovered in the high molecular weight fractions.

\section{DISCUSSION}

In the present study SM activity was detected in the serum of the youngest fetus studied at 66 days gestation and fetal SM activity increased after 100 days. In the fetal pig, serum SM activity, as measured by the somatomedin $\mathrm{C}$ placental membrane receptor assay, has been detected at 24 days gestation (term I15 days) but no correlation between fetal SM concentrations and gestational age was observed (2). In human cord blood SM activity, as measured by porcine cartilage assay between 24 weeks gestation and term correlates with gestational age (6).

In the neonatal rat $(17)$ and in both the human $(2,6,18,19)$ and porcine fetus (2) SM activity is lower than in the adult. In the present study SM activity in the ovine fetus was lower than in the adult ram prior to 100 days but after this rose to higher concentrations than in either the pregnant ewe or adult ram. This species difference remains unexplained. However, there are also species differences in the fetal plasma concentrations of growth hormone. In the ovine fetus the mean GH concentration rises during the last trimester whereas falling $\mathrm{GH}$ concentrations are observed in the human fetus at a comparable gestational age (7).

A further increase in serum SM aclivity was noted in the neonatal sheep as compared to the late gestation fetus. Tato et al (19) reported that in the term newborn human, SM as measured by porcine cartilage bioassay is low in the newborn, rises to adult concentrations by one week of age, and falls to low concentrations by one month. The explanation of the postnatal rise in SM in both the lamb and ewe is uncertain. Estrogen in vivo has been reported to suppress SM activity (22) and the higher postnatal SM concentrations might reflect "release" from the suppressive activity of estrogen during pregnancy.

Somatomedin circulates bound to a high molecular weight binding protein (11). In light of the high SM concentrations in the 